\title{
INFLUENCE OF MAGNESIUM COMPOUNDS ON SODIUM, POTASSIUM AND CALCIUM LEVELS IN DIFFERENT MICE ORGANS
}

\author{
CORINA MOISA ${ }^{1}$, OANA CADAR ${ }^{2 *}$, REKA BARABAS $^{3}$, LAURA GRATIELA VICAS $^{1}$, \\ MARIA-ALEXANDRA HOAGHIA ${ }^{2}$, ERIKA-ANDREA LEVEI ${ }^{2}$, CLAUDIA JURCA ${ }^{1}$, CRISTIAN \\ BERCE $^{4}$
}

${ }^{1}$ University of Oradea, Medicine and Pharmacy Faculty, Department of Pharmacy, 29 Nicolae Jiga Street, 410028, Oradea, Romania ${ }^{2}$ INCDO-INOE 2000, Research Institute for Analytical Instrumentation, 67 Donath Street, 400293, Cluj-Napoca, Romania ${ }^{3}$ Babeș-Bolyai University, Faculty of Chemistry and Chemical Engineering, 11 Arany Janos Street, 400028, Cluj-Napoca, Romania 4 "Iuliu Hațieganu” University of Medicine and Pharmacy, Centre for Experimental Medicine, Laboratory animal facility, 6 Louis Pasteur Street, 400349, Cluj-Napoca, Romania

*corresponding author: oana.cadar@icia.ro

Manuscript received: May 2018

\begin{abstract}
The administration of $\mathrm{Mg}^{2+}$ determines not only the increase of $\mathrm{Mg}^{2+}$, but also induces changes in the tissular levels of $\mathrm{Ca}^{2+}$, $\mathrm{K}^{+}$and $\mathrm{Na}^{+}$. The effects of dietary $\mathrm{Mg}^{2+}$ on macro-elements $\left(\mathrm{Ca}^{2+}, \mathrm{K}^{+}, \mathrm{Na}^{+}\right)$levels in mice tissues (heart, liver, spleen, kidney and lung) were investigated in a murine study. Doses of 300, 200, 100, 50 and $25 \mathrm{mg}$ of different $\mathrm{Mg}$ compounds (orotate, sulphate, oxide, chloride, carbonate, citrate) were administrated by gavage. The results showed that $\mathrm{Na}^{+}$and $\mathrm{K}^{+}$levels increase, while $\mathrm{Ca}^{2+}$ levels decrease with the increase of the $\mathrm{Mg}^{2+}$ level. In all organs, macro-elements levels decrease in the following order: $\mathrm{K}^{+}>\mathrm{Na}^{+}>\mathrm{Ca}^{2+}$. The highest intracellular $\mathrm{Na}^{+}, \mathrm{K}^{+}$and $\mathrm{Ca}^{2+}$ levels were obtained in the case of $\mathrm{Mg}$-orotate administration, while no significant changes in the intracellular $\mathrm{Na}^{+}, \mathrm{K}^{+}$and $\mathrm{Ca}^{2+}$ levels were obtained by $\mathrm{Mg}$ supplementation as oxide, citrate or carbonate. The principal component analysis confirmed that the increase of intracellular $\mathrm{Na}^{+}$is accompanied by the increase of intracellular $\mathrm{K}^{+}$and vice versa. Also, high intracellular $\mathrm{Ca}^{2+}$ levels are expected at low $\mathrm{Mg}^{2+}$ doses.
\end{abstract}

\section{Rezumat}

Administrarea de $\mathrm{Mg}^{2+}$ determină nu numai o creștere a conţinutului de $\mathrm{Mg}^{2+}$, ci şi modificări ale nivelurilor de $\mathrm{Ca}^{2+}, \mathrm{K}^{+}$şi $\mathrm{Na}^{+}$în țesuturi. În această lucrare s-a studiat influența compușilor cu $\mathrm{Mg}^{2+}$ asupra macro-elementelor $\left(\mathrm{Ca}^{2+}, \mathrm{K}^{+}, \mathrm{Na}^{+}\right)$în țesuturile (inimă, ficat, splină, rinichi și plămâni) de şoareci. Au fost administrate doze de 300, 200, 100, 50 și $25 \mathrm{mg}$ de diferiți compuși de $\mathrm{Mg}$ (orotat, sulfat, oxid, clorură, carbonat, citrat) prin gavaj. Rezultatele indică o creștere a nivelurilor de $\mathrm{Na}^{+}$și $\mathrm{K}^{+}$, în timp ce nivelul de $\mathrm{Ca}^{2+}$ scade odată cu creșterea nivelului de $\mathrm{Mg}^{2+}$. În toate organele, nivelul de macro-elemente scade în următoarea ordine: $\mathrm{K}^{+}>\mathrm{Na}^{+}>\mathrm{Ca}^{2+}$. Cele mai mari niveluri intracelulare de $\mathrm{Na}^{+}, \mathrm{K}^{+}$și $\mathrm{Ca}^{2+}$ au fost obținute în cazul administrării de orotat de $\mathrm{Mg}$, în timp ce, ca urmare a administrării de $\mathrm{Mg}^{2+}$ sub formă de oxid, citrat sau carbonat, nu au fost observate schimbări semnificative în nivelul intracelular de $\mathrm{Na}^{+}, \mathrm{K}^{+}$și $\mathrm{Ca}^{2+}$. Analiza componentelor principale a confirmat creșterea $\mathrm{K}^{+}$intracelular odată cu creșterea $\mathrm{Na}^{+}$și vice-versa. De asemenea, concentrații ridicate de $\mathrm{Ca}^{2+}$ intracelular apar la administrarea de doze mici de $\mathrm{Mg}^{2+}$.

Keywords: magnesium compounds, tissue uptake, mice, calcium, potassium, sodium

\section{Introduction}

The major dietary nutrients needed by humans are grouped into macro-nutrients (proteins, carbohydrates and fat) and micronutrients (vitamins and minerals) [1]. The minerals are present in all body tissues and fluids, their presence being necessary to maintain the physicochemical processes that are essential for life $[8,19]$. Dietary supplements are ingested in order to supply microand macro- nutrients that are lacking in the diet, to maintain or improve health, to support a particular body function (like immunity or cardiovascular status), to reduce health risks and to prevent diseases $[9,14,23]$.
Calcium $\left(\mathrm{Ca}^{2+}\right)$, magnesium $\left(\mathrm{Mg}^{2+}\right)$, sodium $\left(\mathrm{Na}^{+}\right)$ and potassium $\left(\mathrm{K}^{+}\right)$have important roles in numerous biologic and cellular functions [4]. $\mathrm{Mg}^{2+}$ and $\mathrm{K}^{+}$are the main intracellular cations, while $\mathrm{Na}^{+}$ and $\mathrm{Ca}^{2+}$ are mainly extracellular ions, but only some of their compounds exhibit good intracellular absorption $[10,14,24] . \mathrm{K}^{+}$plays a vital role in the heart and skeletal muscle contraction, nerve conduction and renal function, while $\mathrm{Ca}^{2+}$ mediates muscle contraction and controls the exocrine, endocrine and neurocrine functions. $\mathrm{Mg}^{2+}$ has an important role in enzyme activation, energy metabolism, synthesis of proteins and DNA, $\mathrm{Ca}^{2+}$ 
and $\mathrm{K}^{+}$flux regulation, bone formation, neuromuscular excitability, while $\mathrm{Na}^{+}$has a crucial role in the excitability of muscles and neurons and in the regulation of body fluids [4, 17, 18]. These elements are absorbed from the gastrointestinal tract and excreted by the kidneys, their homeostasis being balanced by these mechanisms. The main $\mathrm{Mg}^{2+}$ reserves are kept in the skeletal muscle, while the main $\mathrm{Ca}^{2+}$ reserves in the structural bones [17]. When the body reserves of electrolytes $\left(\mathrm{Na}^{+}, \mathrm{K}^{+}\right.$, $\mathrm{Ca}^{2+}$ and $\mathrm{Mg}^{2+}$ ) decrease, the gastrointestinal absorption, bone and renal resorption increase to normalize their levels [4]. $\mathrm{K}^{+}$and $\mathrm{Mg}^{2+}$ deficiency significantly alters the functions of cell membranes, in terms of ionic permeability. Small changes in the serum $\mathrm{K}^{+}$can affect various body functions like heart rhythm and skeletal muscle function. In the case of hypomagnesemia, it is impossible to correct the intracellular $\mathrm{K}^{+}$deficiency $[7,11,13,16]$.

There is no correlation between the plasma and intracellular electrolyte content [21]. $\mathrm{Ca}^{2+}$ antagonizes the effects of $\mathrm{K}^{+}$and $\mathrm{Mg}^{2+}$ at the cell membranes, being very useful in the treatment of hyperkalemia and hypermagnesemia [7, 13, 16]. The effect of micronutrients in the body's physiological need is not entirely understood through all organs and systems. Usually, the micronutrients are required in the cells and tissues and might undergo a specific metabolic route within the cells. Although the blood is the main delivery route for almost all nutrients toward cells and tissues, its composition may not reflect the real nutrient status of cells. Moreover, the traditional targets as blood, urine and hair do not always reflect correctly the nutrients level in the body. As a result, there is a need to develop suitable methods to determine the nutritional status [3]. As the serum concentration does not correlate with the tissular $\mathrm{Ca}^{2+}$ or $\mathrm{Mg}^{2+}$, deficiencies are difficult to identify, due to their easy migration into bones, muscles, soft tissue and other body parts. Only $0.3 \%$ of the total body $\mathrm{Mg}^{2+}$ is present in serum and $1 \%$ in the extracellular fluids; the highest part represents free $\mathrm{Mg}^{2+}$, the other part being bonded to plasmatic proteins. A similar situation was observed for $\mathrm{Ca}^{2+}$ [20]. Moreover, $\mathrm{Mg}^{2+}$ strongly interacts with $\mathrm{Ca}^{2+}$ and $\mathrm{K}^{+}$, the deficiency-excess of one cation influencing the effects of the others $[5,12,22,26]$. A large part of the population is confronting stress, sleeping disorders and chronic fatigue. In half of the cases, besides this symptoms $\mathrm{Mg}$ deficiency also appears. This finding made magnesium supplements gaining much attention. Moreover, magnesium formulations are among the most commonly used supplements. Our previous studies described the $\mathrm{Mg}^{2+}$ levels of mice tissues (heart, liver, spleen, kidneys and lungs) after administration of different $\mathrm{Mg}^{2+}$ compounds (orotate, sulphate, oxide, chloride, carbonate, citrate). Despite the fact that translating the results of animal experiments to humans is sometime difficult or subject to failure, mice models allow elucidating the role of supplements in the organism, give insights on their metabolism and allow identification of their function in key biochemical and physiologic processes. Small changes in plasma $\mathrm{Mg}^{2+}$ level induce modifications of other ions $\left(\mathrm{K}^{+}\right.$, $\mathrm{Na}^{+}$and $\left.\mathrm{Ca}^{2+}\right)$. The treatment of $\mathrm{Mg}^{2+}$ deficiency and assurance of optimum intracellular levels of $\mathrm{Ca}^{2+}, \mathrm{K}^{+}$and $\mathrm{Na}^{+}$depend on the $\mathrm{Mg}^{2+}$ source utilized in the therapy. In this study, the influence of most frequently used $\mathrm{Mg}^{2+}$ supplements on $\mathrm{K}^{+}$, $\mathrm{Na}^{+}$and $\mathrm{Ca}^{2+}$ levels in different mice tissues has been investigated. Furthermore, Principal Component Analysis (PCA) was used to reveal the relationships between the levels of different macrominerals and to differentiate the supplements by dose and formulation.

\section{Materials and Methods}

$\mathrm{Mg}^{2+}$ compounds (orotate, sulphate, oxide, chloride, carbonate, citrate), $65 \% \mathrm{HNO}_{3}$ and $30 \%$ $\mathrm{H}_{2} \mathrm{O}_{2}$ were purchased from Merck, Germany. A multi-elemental standard solution of $1000 \mathrm{mg} / \mathrm{L}$ (Merck, Germany) containing the analysed elements $\left(\mathrm{Na}^{+}, \mathrm{K}^{+}\right.$and $\left.\mathrm{Ca}^{2+}\right)$ was used for inductively coupled plasma optical emission spectrometer (ICP-OES) calibration. For all dilutions, ultrapure water $(18.2 \mathrm{M} \Omega / \mathrm{cm})$ obtained from a Millipore Direct-Q3 UV system (Millipore, France) was used.

A number of 62 adult male Crl:CD1(ICR) mice with an average weight of $26.92 \pm 0.21 \mathrm{~g}$ were used in the study as previously described by Moisa et al. [15]. Amounts of 25, 50, 100, 200 and $300 \mathrm{mg}$ of $\mathrm{Mg}^{2+}$ compounds were dissolved (orotate, sulphate, chloride and citrate) or suspended (carbonate, oxide) in distilled water and administered by gavage. In the case of the control group, distilled water was administered. After $48 \mathrm{~h}$, the animals were euthanized by cervical dislocation. The heart, lung, liver, spleen and kidney were used [2]. In each organ, the $\mathrm{Na}^{+}, \mathrm{K}^{+}$and $\mathrm{Ca}^{2+}$ concentrations were determined $(\mathrm{mg} / \mathrm{kg})$ by using Optima 5300 DV ICP-OES (Perkin Elmer, USA), after microwave digestion (MW). The digestion was performed on about $200 \mathrm{mg}$ organ tissue, using $\mathrm{HNO}_{3} / \mathrm{H}_{2} \mathrm{O}_{2} \quad(10 / 1, \quad \mathrm{v} / \mathrm{v})$ in closed polytetrafluoroethylene (PTFE) vessel MW system (Berghof MWS-3+, Eningen, Germany) according to the method described by Zhao et al. [25]. The operating conditions used for ICP-OES determination were: $1300 \mathrm{~W}$ RF power, $15 \mathrm{~L} / \mathrm{min}$ plasma flow, $2.0 \mathrm{~L} / \mathrm{min}$ auxiliary flow, $0.8 \mathrm{~L} / \mathrm{min}$ nebulizer flow and $1.5 \mathrm{~mL} / \mathrm{min}$ sample uptake rate. 
The calibration standards $(0.1,0.2,0.5,1,2,4$ and $6 \mathrm{mg} / \mathrm{L})$ were prepared from multi-elemental standard after appropriate dilution. The accuracy of the analytical results was assured by analysing 3 replicates and a certified reference material (CRM). Beef/pork meat CRM (LGC7000, LGC Standards $\mathrm{GmbH}$, Germany) was used for quality assurance. The recoveries $(\%)$, calculated using the average of three replicates were in the range of $90-106 \%$.

Statistical analysis

To interpret the dataset structure, principal component analysis (PCA) with varimax rotation was performed using the XL Stat Microsoft Excel plug-in (Addinsoft).

\section{Results and Discussion}

Generally, for multi-elemental analysis of nonliquid samples using ICP-OES, a digestion or dissolution step should be included prior the instrumental analysis. MW digestion is a powerful sample preparation method with considerable advantages over the conventional digestion method: low consumption of reagents and time and reduced contamination. The disadvantage of the MW method is that it is more expensive and requires some experience [6]. The main advantages of ICPOES method is the capability for analysing almost all the elements in the periodic table, wide linear dynamic ranges, good sensitivity, limited spectral and chemical interferences, low detection limits, capacity to measure trace to high concentrations, short analysis time (1 $\mathrm{min})$, low sample consumption $(0.5-1.0 \mathrm{~mL})$ and reasonable costs. The main disadvantage of ICP-OES is that the technique is sample destructive.

The tissular $\mathrm{Na}^{+}, \mathrm{Ca}^{2+}$ and $\mathrm{K}^{+}$levels, after administration of different doses of various $\mathrm{Mg}^{2+}$ formulations are presented in Figures 1 and 2 . Generally, the macro-elements contents decreases in the order $\mathrm{K}^{+}>\mathrm{Na}^{+}>\mathrm{Ca}^{2+}$, in all organs.
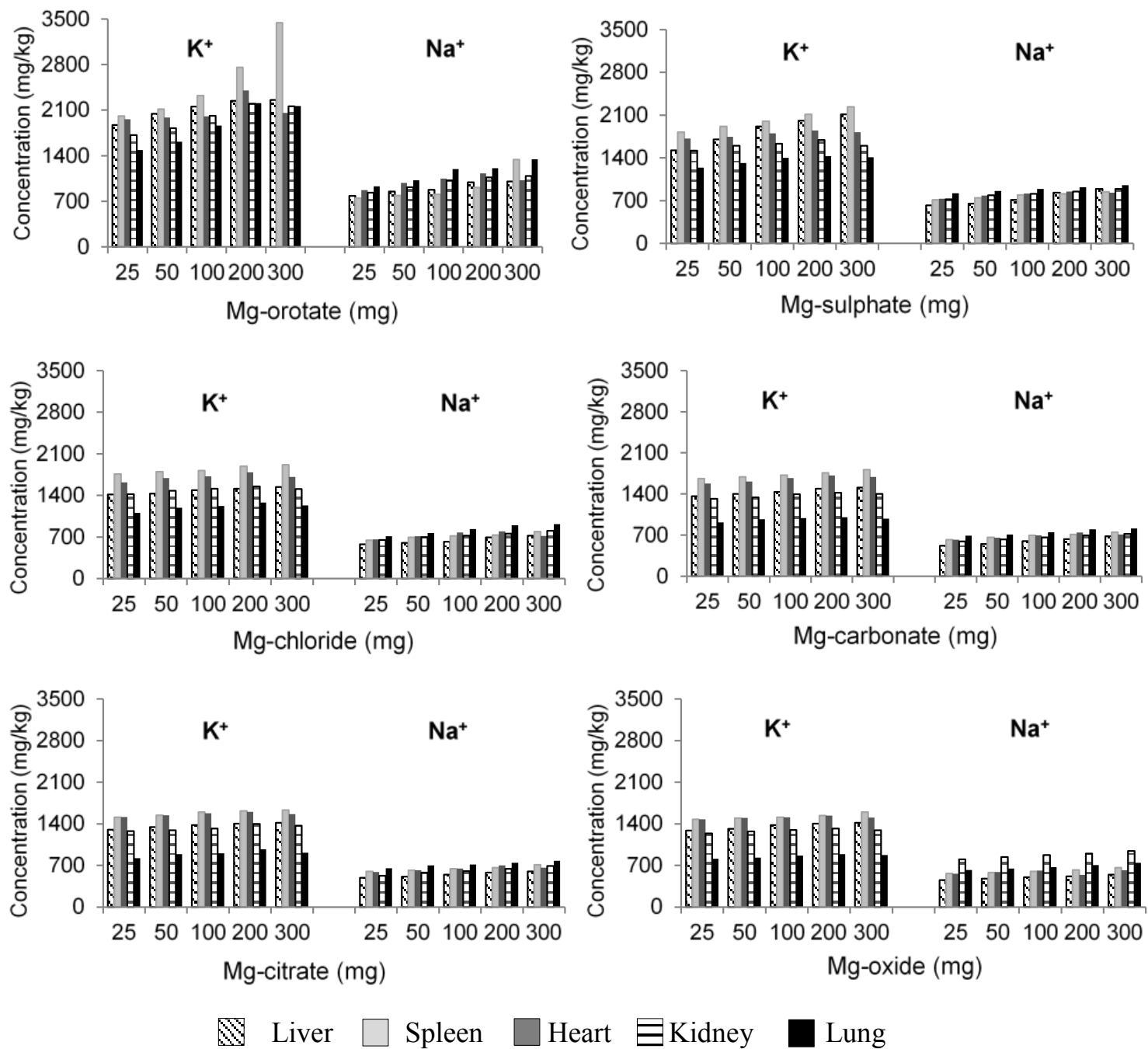

$\mathbb{N}$ Liver $\square$ Spleen $\square$ Heart $\equiv$ Kidney $\square$ Lung

Figure 1.

The $\mathrm{K}^{+}$and $\mathrm{Na}^{+}$concentrations in organs after the administration of various compounds and doses of $\mathrm{Mg}$ supplements 
The $\mathrm{Ca}^{2+}$ content decreases, while the $\mathrm{Na}^{+}$and $\mathrm{K}^{+}$ contents increase with the increase of the $\mathrm{Mg}^{2+}$ content. The lowest $\mathrm{K}^{+}$content is found in lung $(811 \mathrm{mg} / \mathrm{kg})$, while the highest in spleen $(3443$ $\mathrm{mg} / \mathrm{kg}$ ). The median $\mathrm{K}^{+}$concentration decreases in the order: spleen $>$ heart $>$ liver $\geq$ kidney $>$ lung. The $\mathrm{Na}^{+}$content ranged between $453 \mathrm{mg} / \mathrm{kg}$ (liver) and $1344 \mathrm{mg} / \mathrm{kg}$ (lung), the median $\mathrm{Na}^{+}$decreasing in the order lung $\geq$ kidney $>$ heart $>$ spleen $>$ liver. The highest concentration of $\mathrm{Na}^{+}$is found in the extracellular space, its homeostasis being controlled by the kidneys [16]. Moreover, the $\mathrm{K}^{+}$increase favours the renal excretion of $\mathrm{Na}^{+}$.

The lowest $\mathrm{Ca}^{2+}$ content is found in the kidney $(17.3 \mathrm{mg} / \mathrm{kg})$, while the highest in the heart (111 $\mathrm{mg} / \mathrm{kg}$ ), the median $\mathrm{Ca}^{2+}$ decreasing in the following order: heart $\geq$ lung $>$ spleen $\geq$ liver $>$ kidney, probably because $\mathrm{Ca}^{2+}$ is excreted in the kidney. $\mathrm{Ca}^{2+}$ has an opposing effect to $\mathrm{K}^{+}$and $\mathrm{Mg}^{2+}$ at the cellular membrane level.
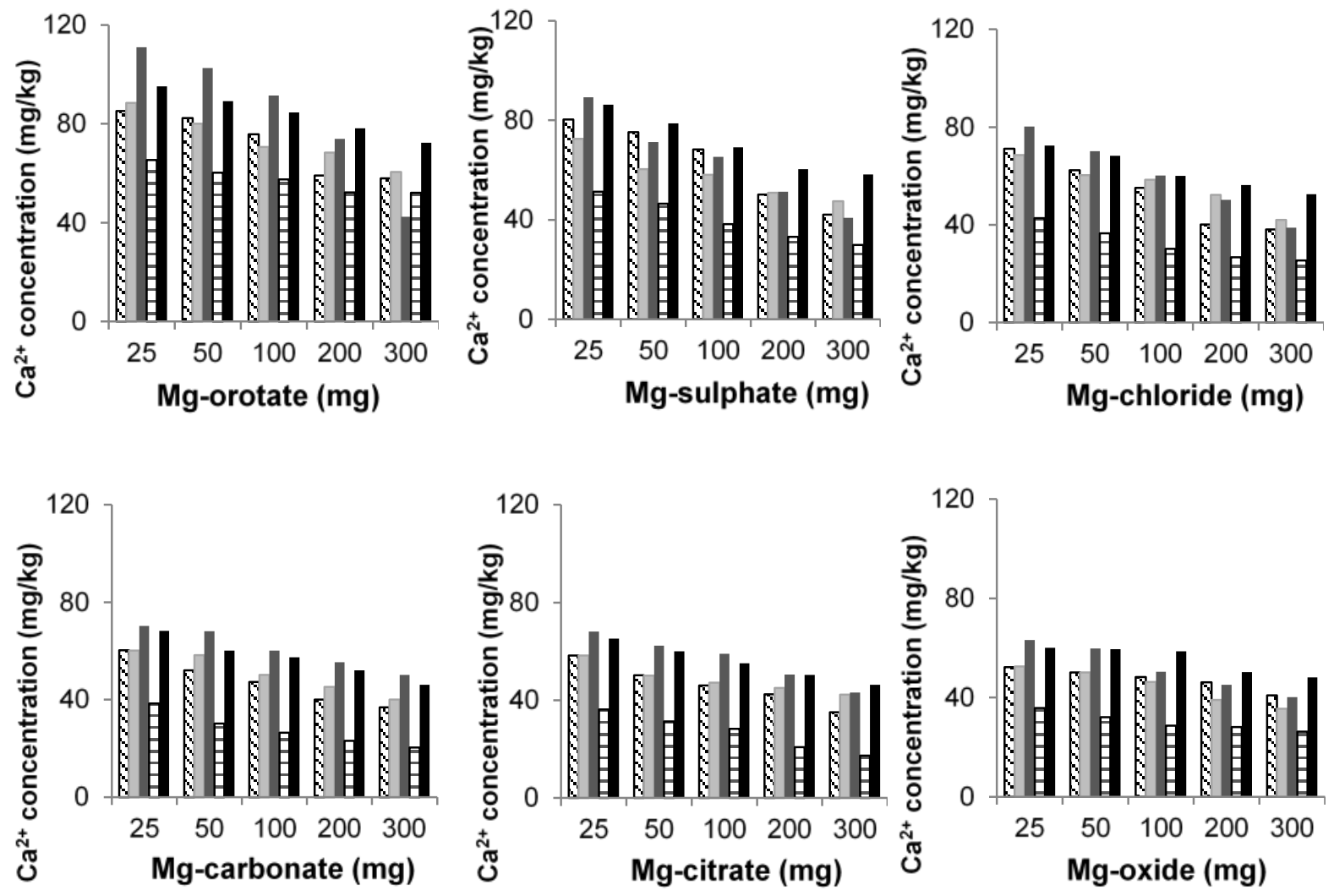

Liver

$\triangle$ Spleen

$\square$ Heart

ĐKidney

Lung

Figure 2.

$\mathrm{Ca}^{2+}$ concentration in organs after the administration of various compounds and doses of $\mathrm{Mg}$ supplements

The velocity of $\mathrm{K}^{+}$exchange between cells and interstitial liquid vary from organ to organ, reaching the highest values in kidneys and lungs. $\mathrm{Ca}^{2+}$ induces cell excitability that depends on the $\mathrm{Na}^{+}$activity. The decrease of the $\mathrm{Ca}^{2+}$ level has the effect of increasing the membranes permeability for $\mathrm{Na}^{+}$[11]. A high extracellular $\mathrm{Na}^{+}$level leads to positive electric charges accumulation outside the cell wall, as well as cell membranes tension. Any other outside stimulus determines the membrane repolarization. By increasing the $\mathrm{Mg}^{2+}$ orotate dose, the $\mathrm{K}^{+}$level increases in spleen, kidney and lung, while in the liver remains constant independently of the administered dose. A possible explanation could be the role of $\mathrm{Mg}^{2+}$ in the regulation of intracellular $\mathrm{K}^{+}$level. In case of the other $\mathrm{Mg}^{2+}$ supplements, no significant variation of the $\mathrm{K}^{+}$level with the increase of the $\mathrm{Mg}^{2+}$ dose was observed, in any of the studied organs. The $\mathrm{Na}^{+}$level was not influenced by the administration of $\mathrm{Mg}^{2+}$ supplements. 


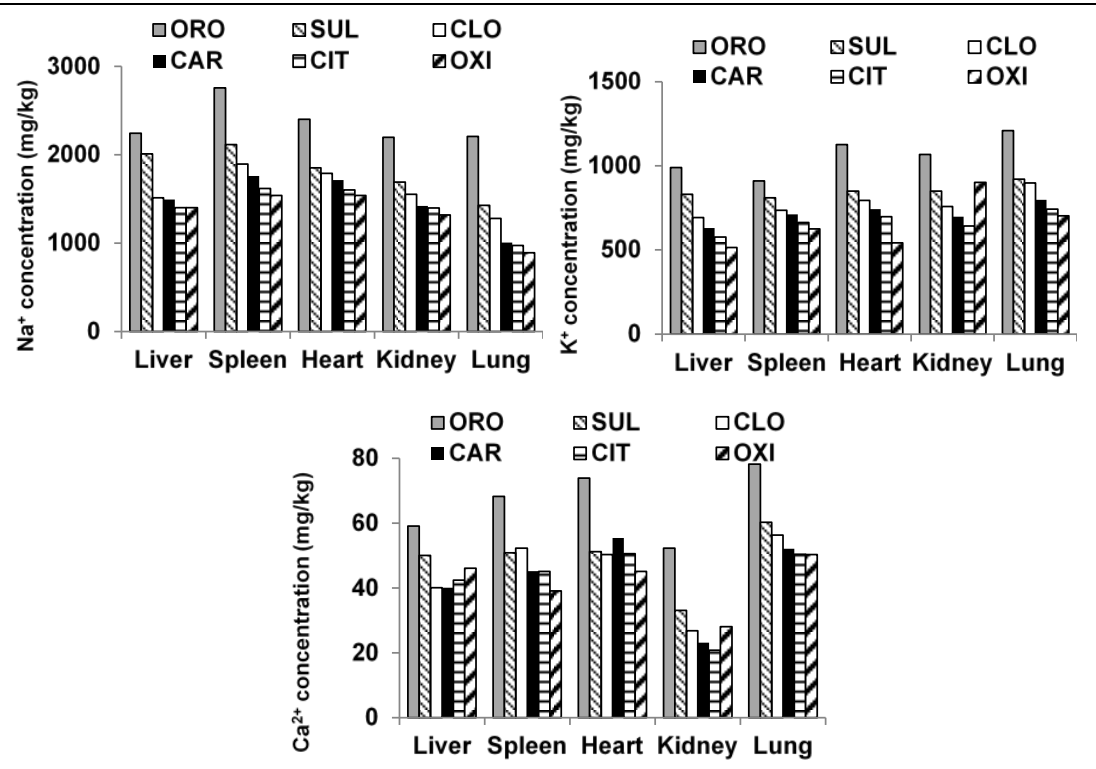

Figure 3.

The $\mathrm{Na}^{+}, \mathrm{K}^{+}$and $\mathrm{Ca}^{2+}$ concentrations in organs after the administration of $200 \mathrm{mg}$ of various $\mathrm{Mg}$ supplements, where $\mathrm{ORO}=$ orotate, $\mathrm{SUL}=$ sulphate, $\mathrm{CLO}=$ chloride, $\mathrm{CAR}=$ carbonate, $\mathrm{CIT}=$ citrate, $\mathrm{OXI}=$ oxide

Generally, the $\mathrm{Ca}^{2+}$ level was not influenced by the dose of $\mathrm{Mg}^{2+}$ supplements; however, for all supplements, in hearth, an inverse relationship between the $\mathrm{Mg}^{2+}$ dose and the $\mathrm{Ca}^{2+}$ level was registered.

In order to identify a relationship between the $\mathrm{Na}^{+}$, $\mathrm{K}^{+}$and $\mathrm{Ca}^{2+}$ levels and different salts, the $\mathrm{Mg}$ supplements were compared at a single dose of 200 $\mathrm{mg}$. Figure 3 shows that the highest levels of intracellular $\mathrm{Na}^{+}, \mathrm{K}^{+}$and $\mathrm{Ca}^{2+}$ were obtained for $\mathrm{Mg}^{2+}$ orotate administration. No significant changes in the intracellular $\mathrm{Na}^{+}, \mathrm{K}^{+}$and $\mathrm{Ca}^{2+}$ levels were obtained by dosing $\mathrm{Mg}^{2+}$ supplement in the form of oxide,

citrate

or carbonate.
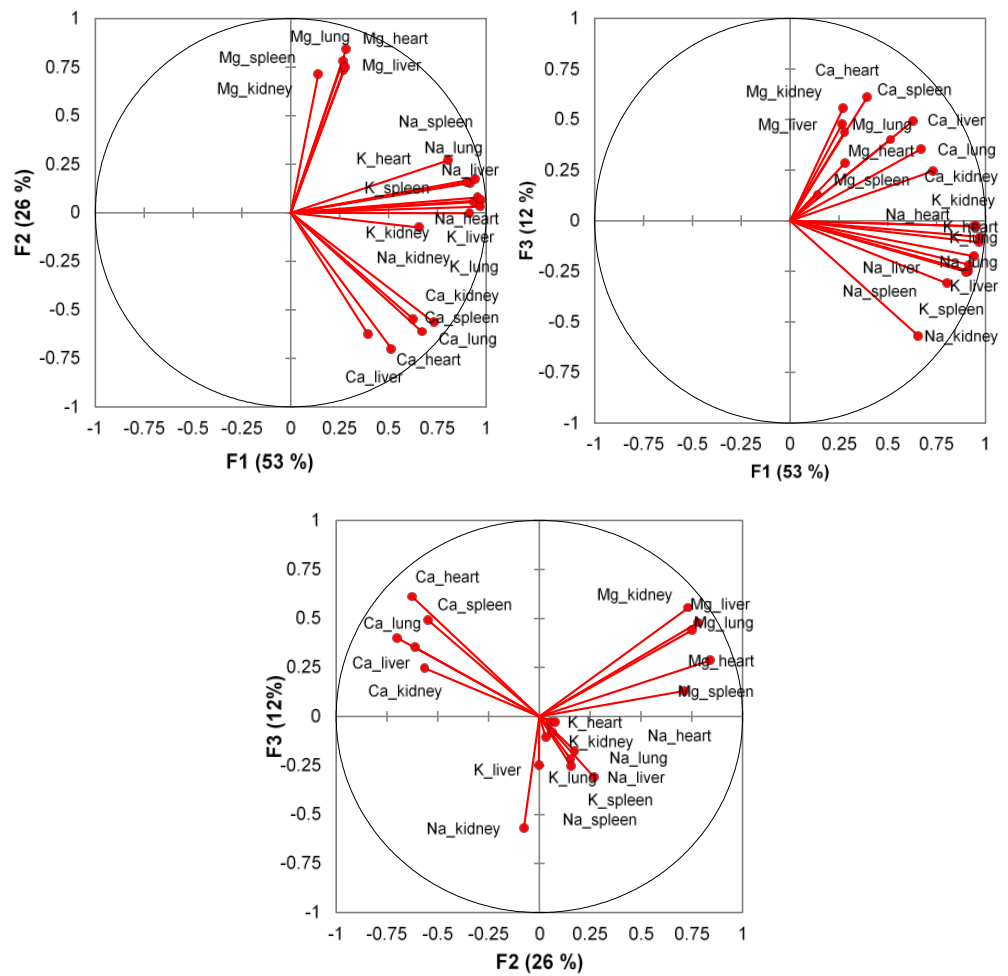

Figure 4.

Projection of factor loadings on the principal components 
PCA was applied to intracellular levels of $\mathrm{K}^{+}, \mathrm{Na}^{+}$, $\mathrm{Mg}^{2+}$ and $\mathrm{Ca}^{2+}$ to reduce and visualize the data structure. The linear combinations of original variables are named principal components (PCs). According to the Kaiser criterion, only the PC's with eigenvalue higher than 1.0 was retained and subjected to varimax rotation. The varimax rotated loadings of the 3 PC's with eigenvalues $>1.0$ explains $91 \%$ of the system variability. The factor loadings (Figure 4) show the correlation of PCs with the original variables and among PCs. The first factor (PC1) accounting for 53\% of the total variance (loadings $>0.7$ ) is related to the intracellular levels of $\mathrm{Na}^{+}$and $\mathrm{K}^{+}$, suggesting that the increase of intracellular $\mathrm{Na}^{+}$will be accompanied also by the increase of intracellular $\mathrm{K}^{+}$and vice versa.
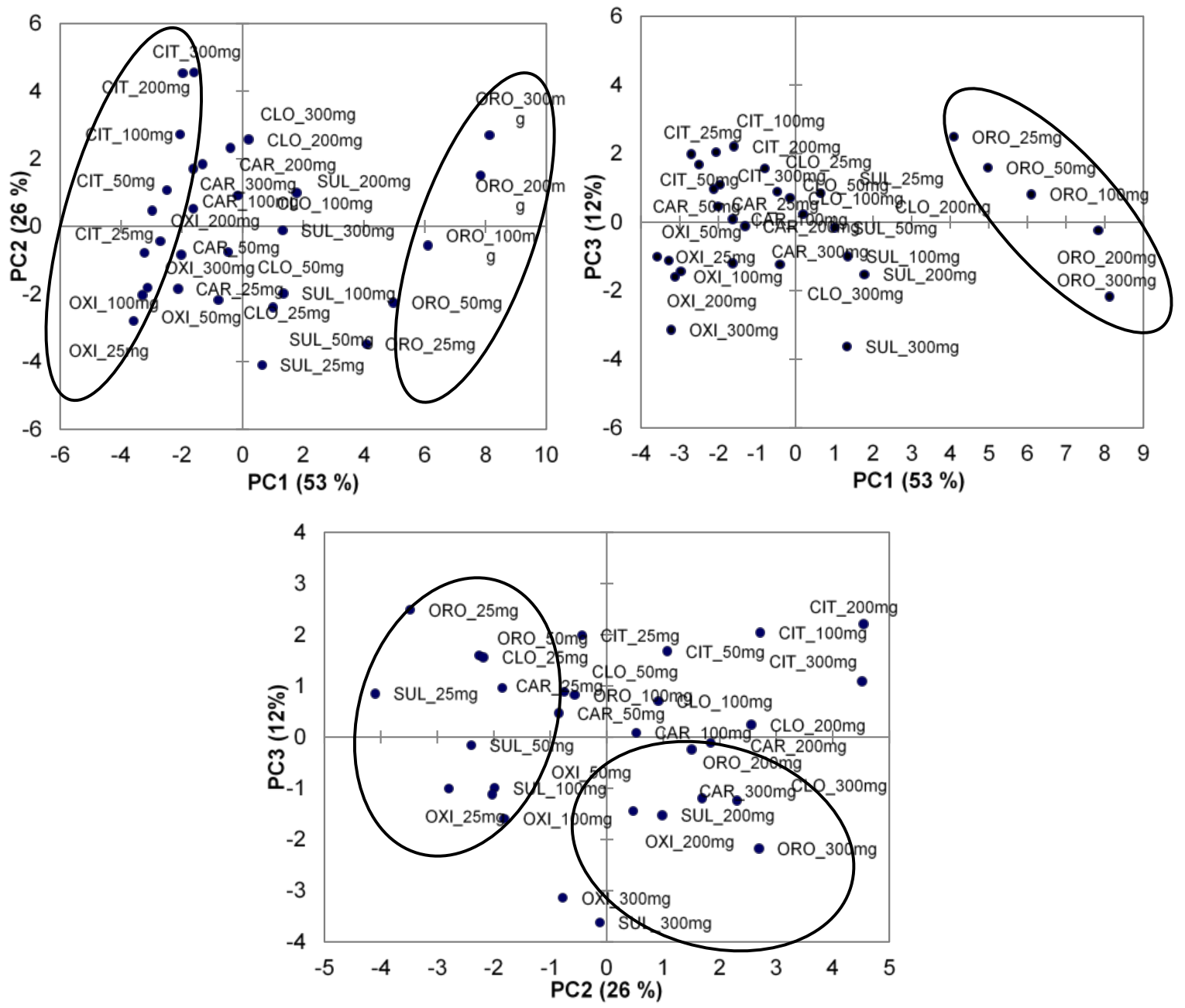

Figure 5.

Scatter plots of the PCs

The second PC2 with a contribution of $26 \%$ was associated to $\mathrm{Mg}^{2+}$, and suggests that $\mathrm{Mg}^{2+}$ level is directly proportional with $\mathrm{Na}^{+}$and $\mathrm{K}^{+}$levels and inversely proportional with $\mathrm{Ca}^{2+}$ levels. The third PC3 (12\%) was associated to $\mathrm{Ca}^{2+}$ and suggests that the $\mathrm{Ca}^{2+}$ levels are inversely correlated with the $\mathrm{Na}^{+}$ and $\mathrm{K}^{+}$levels. The biplots (Figure 5) reveal that $\mathrm{Na}^{+}$and $\mathrm{K}^{+}$intracellular level (PC1) distinguish between orotate, citrate and oxide, but does not separate the other supplements, while the $\mathrm{Mg}^{2+}$ levels (PC2) differentiate between orotate and the other supplements. The $\mathrm{Ca}^{2+}$ level (PC3) differentiates supplements by dose but not by the salt used. Thus, in the case of $\mathrm{Mg}^{2+}$ orotate supplement administration, the intracellular $\mathrm{Na}^{+}$ and $\mathrm{K}^{+}$concentrations are expected to be high, while in the case of the citrate and oxide supplements administration the $\mathrm{Na}^{+}$and $\mathrm{K}^{+}$ concentrations are expected to be low. Also, high intracellular $\mathrm{Ca}^{2+}$ contents are expected at low $\mathrm{Mg}^{2+}$ doses and low $\mathrm{Ca}^{2+}$ contents at high $\mathrm{Mg}^{2+}$ doses.

$\mathrm{Na}^{+}, \mathrm{K}^{+}, \mathrm{Ca}^{2+}$ and $\mathrm{Mg}^{2+}$ regulate the neuromuscular excitability and the coagulation mechanism; therefore, the closer monitoring of $\mathrm{Mg}^{2+}$ level is very important in cardiac patients. A low $\mathrm{Mg}^{2+}$ plasmatic concentration (hypomagnesemia) 
FARMACIA, 2019, Vol. 67, 2

increases the cardiac excitability, cardiac arrhythmias, while a high $\mathrm{Mg}^{2+}$ concentration (hypermagnesemia) suppresses the cardiac conducting system. The intracellular $\mathrm{K}^{+}, \mathrm{Ca}^{2+}$ and $\mathrm{Mg}^{2+}$ concentrations are closely linked, any deficiency influencing the other elements levels. $\mathrm{Mg}^{2+}$ plays an important role in maintaining adequate intracellular $\mathrm{Ca}^{2+}$ levels (e.g. $\mathrm{Mg}^{2+}$ deficiency influences the mobility of $\mathrm{Ca}^{2+}$ in bones) $[4,5]$. Furthermore, $\mathrm{Mg}^{2+}$ is excreted renally, resulting in high $\mathrm{Mg}^{2+}$ levels in kidneys compared to other macro-elements/organs.

The obtained results indicate higher variations of intracellular $\mathrm{Ca}^{2+}, \mathrm{K}^{+}$and $\mathrm{Na}^{+}$in the studied organs after the $\mathrm{Mg}^{2+}$ orotate administration compared to other $\mathrm{Mg}^{2+}$ compounds (sulphate, oxide, chloride, carbonate and magnesium citrate). A possible explanation could be the more effective $\mathrm{Mg}^{2+}$ absorption, at the intracellular level, after the administration of $\mathrm{Mg}^{2+}$ orotate. Thus, $\mathrm{Mg}^{2+}$ orotate can be used to supplement the $\mathrm{Mg}^{2+}$ level in the human body, considering the lack of secondary effects after administration and the efficient adsorption at the intracellular level.

\section{Conclusions}

The determination of $\mathrm{Mg}^{2+}$ concentration in the human body (blood, serum, tissues, skeleton) is recommended to assess the renal function, gastrointestinal disorder, electrolytes level, neuromuscular activities and cardiac function. The administration of $\mathrm{Mg}^{2+}$ supplements determined variations of $\mathrm{K}^{+}, \mathrm{Na}^{+}$and $\mathrm{Ca}^{2+}$ in all assessed mice tissues (heart, liver, spleen, kidney and lung). The most important variations were observed after the administration of $\mathrm{Mg}$-orotate, probably due to the chemical structure of this compound that allows better $\mathrm{Mg}^{2+}$ absorption at the intracellular level. The highest macro-elements concentrations were found in heart $\left(\mathrm{Ca}^{2+}\right)$, spleen $\left(\mathrm{K}^{+}\right)$and lung $\left(\mathrm{Na}^{+}\right)$tissues. The increase of the $\mathrm{Mg}^{2+}$ content determines the increase of $\mathrm{K}^{+}$and $\mathrm{Na}^{+}$and decrease of $\mathrm{Ca}^{2+}$ levels in tissues. A high amount of $\mathrm{Mg}^{2+}$ was determined in kidney, probably due to its capacity to rapidly excrete large amounts of $\mathrm{Mg}^{2+}$. Furthermore, a low $\mathrm{Mg}^{2+}$ level interferes with the effects of the parathyroid hormones, decreasing the amount of $\mathrm{Ca}^{2+}$ and $\mathrm{K}^{+}$. Regardless of the administered $\mathrm{Mg}^{2+}$ dose and particular compound, the macro-elements levels decreased in the following order: $\mathrm{K}^{+}>\mathrm{Na}^{+}>$ $\mathrm{Ca}^{2+}$, but some differences between the administrated $\mathrm{Mg}^{2+}$ compounds were noticed. The PCA revealed differences between the effect of $\mathrm{Mg}$-orotate, Mg-citrate and $\mathrm{Mg}$-oxide supplements on the intracellular $\mathrm{Na}^{+}$and $\mathrm{K}^{+}$level,

\section{References}

1. Badea M, Chiperea C, Balan M, Floroian L, Restani P, Marty JL, Iovan C, Tit DM, Bungau S, Taus N, New approaches for electrochemical detection of ascorbic acid. Farmacia, 2018; 66(1): 83-87.

2. Berce C, Lucan C, Petrushev B, Boca S, Miclean M, Sarpataki O, Astilean S, Buzoianu A, Tomuleasa C, Boian A, In vivo assessment of bone marrow toxicity by gold nanoparticle-based bioconjugates in Crl:CD1(ICR) mice. Int J Nanomedicine, 2016; 11: 4261-4273.

3. Bielsaki HK, Tinz J, Multivitamin/mineral supplements: Rationale and safety. Nutrition, 2017; 36: 60-66.

4. Blaine J, Chonchol M, Levi M, Renal control of calcium, phosphate, and magnesium homeostasis. Clin J Am Soc Nephrol., 2015; 10(7): 1257-1272.

5. Brodziak-Dopierala B, Kwapulinski J, Sobczyk K, Wiechula D, Distribution of magnesium, calcium, sodium and potassium in tissues of the hip joint. Magnes Res., 2013; 26: 125-131.

6. Cadar O, Miclean M, Cadar S, Tanaselia C, Senila L, Senila M, Assessment of heavy metals in cows milk in Rodnei mountains area, Romania. Environ Eng Manag J., 2015; 14: 2523-2528.

7. Chang X, Glessner J, Tin A, Li J, Guo Y, Wei Z, Liu Y, Mentch FD, Cuiping H, Zhao Y, Wang T, Qiu H, Kim C, Sleiman PMA, Hakonarson H, Genome-wide association study reveals two loci for serum magnesium concentrations in European-American children. Sci Rep., 2015; 5: 1-5.

8. Collins J, Molecular, genetic, and nutritional aspects of major and trace minerals. Elsevier Academic Press, 2016, pp. 3.

9. Costea T, Istudor V, Fierareascu R, Fierareascu I, Botez A, Research upon indigenous herbal products for therapeutic valorification in metabolic diseases note I. Betulae folium and Rubi idaei folium, sources of micro-and macroelements. Farmacia, 2013; 61(1): 162-169.

10. Coudray C, Rambeau M, Feillet-Coudray C, Gueux E, Tressol JC, Mazur A, Rayssiguier Y, Study of magnesium bioavailability from ten organic and inorganic $\mathrm{Mg}$ salts in $\mathrm{Mg}$-depleted rats using a stable isotope approach. Magnes Res., 2005; 18: 215-223.

11. Grozav A, Porumb ID, Gaina LI, Filip L, Hanganu D, Cytotoxicity and antioxidant potential of novel 2-(2((1H-indol-5yl)methylene)-hydrazinyl)-thiazole Derivatives. Molecules, 2017; 22: 260-272.

12. Jahnen-Dechent W, Ketteler M, Magnesium basics. Clin Kidney J., 2012; 5: i3-i14.

13. Lüderitz B, Potassium deficiency and cardiac function: experimental and clinical aspects. Magnesium, 1984; 3: 289-300.

14. Moisa C, Hoaghia MA, Simedru D, Cadar O, Influence of tablet formulation on in vitro release of magnesium. Studia U Babes-Bol Che., 2016; 3: 441449.

15. Moisa C, Vicas LG, Ganea M, Levei EA, Cadar O, Berce C, Murine studies regarding the tissue intake of different magnesium compounds. Farmacia, 2018; 66(1): 176-180. 
16. Ortega B, MacWilliams JR, Dey JM, Courtright VB, Hyperphosphatemia, hypocalcemia and increased serum potassium concentration as distinctive features of early hypomagnesemia in magnesium-deprived mice. Magnes Res., 2015; 28: 126-135.

17. Parikh M, Webb ST, Cations: potassium, calcium, and magnesium, Continuing Education in Anaesthesia Critical Care \& Pain, 2012; 12(4): 195-198.

18. Pantea-Stoian A, Pițuru SM, Hainăroșie R, Andronache LF, Ginghină O, Serafinceanu C, Testosterone therapy, new opportunities in diabetes mellitus. Farmacia, 2018; 66(1): 1-7.

19. Rautiainen S, Manson JE, Lichtenstein AH, Sesso HD, Dietary supplements and disease prevention - a global overview. Nat Rev Endocrinol., 2016; 12: 407420.

20. Sato N, Sasaki R, Imahashi M, Ito E, Saito K, Kubota K, Talib AK, Sakamoto N, Akasaka K, Saijo Y, Kawamura Y, Fujii S, Hasebe N, The relationship between repolarization parameters and serum electrolyte levels in patients with $\mathrm{J}$ wave syndromes. Magnes Res., 2015; 28: 1-13.

21. Schwinger RH, Erdmann E, Heart failure and electrolyte disturbances. Methods Find Exp Clin Pharmacol., 1992; 14: 315-225.
22. Sun L, Kosugi Y, Kawakami E, Piao YS, Hashimoto $\mathrm{T}$, Oyanagi $\mathrm{K}$, Magnesium concentration in the cerebrospinal fluid of mice and its response to changes in serum magnesium concentration. Magnes Res., 2009; 22: 262-265.

23. Taschina M, Copolovici DM, Bungău S, Lupitu AI, Copolovici L, Iovan $\mathrm{C}$, The influence of residual acetaminophen on Phaseolus vulgaris L. Secondary metabolites. Farmacia, 2017; 65(5): 709-713.

24. Walker AF, Marakis G, Christie S, Byng M, Magnesium citrate found more bioavailable than other magnesium preparations in a randomised, doubleblind study. Magnes Res., 2003; 16: 183-191.

25. Zhao D, Wang T, Nahan K, Guo X, Zhang Z, Dong Z, Chen S, Chou DT, Hong D, Kumta PN, Heinman $\mathrm{WR}$, In vivo characterization of magnesium alloy biodegradation using electrochemical $\mathrm{H}_{2}$ monitoring, ICP-MS and XPS. Acta Biomater., 2017; 50: 556-565.

26. Zhou Q, Kummerow F, Intracellular free calcium content plays a role in low magnesium- induced increases in prostacyclin production. Magnes Res., 2012; $25: 1-11$ 